\title{
Hereditary forms of subcortical small vessel disease. The need for registries
}

\author{
George P Paraskevas ${ }^{1 *}$, Vasilios C Constantinides ${ }^{1}$, Evangelia Kararizou ${ }^{1}$, Sophia Vassilopoulou${ }^{1}$, Panagiotis G Paraskevas ${ }^{2}$ and Elisabeth \\ Kapaki $^{1}$ \\ ${ }^{1} 1^{\text {st }}$ Department of Neurology, School of Medicine, National and Kapodistrian University of Athens, Eginition Hospital, Greece \\ ${ }^{2}$ Department of Nursing, Technological Educational Institute of Crete, School of Health and Welfare Services, Heraklion, Greece
}

\begin{abstract}
Hereditary forms of subcortical small vessel disease (SSVD) leading to vascular cognitive impairment (VCI) comprise a heterogeneous group of rare genetic disorders, suitable for the study of the mechanisms and relationship between SSVD and VCI. Since these disorders are rare, better knowledge of their clinical, genetic, imaging and biochemical characteristics may be achievable only through registries which additional may help in better recruitment of patients for studies. A great amount of our current knowledge on these disorders has been gained through registries and data bases. International registries may further help in expanding our experience in epidemiological or even preventive and therapeutic aspects of hereditary SSVD.
\end{abstract}

\section{Introduction}

Hereditary cerebral angiopthies comprise a heterogeneous group of rare genetic disorders [1] leading to ischemic and/or hemorrhagic stroke, subcortical small vessel disease (SSVD) and vascular cognitive impairment (VCI) [2]. Among many others, the most widely known of these disorders are cerebral autosomal dominant arteriopathy with subcortical infarcts and leucoancepahlopathy (CADASIL) due to NOTCH3 mutations [3], disorders due to mutations of the genes encoding either alpha1 or alpha2 chain of collagen type IV (COL4A1, COL4A2) [4] and mutations of the HTRA1 gene, including cerebral autosomal recessive arteriopathy with subcortical infarcts and leukoencephalopathy (CARASIL) [5,6]. Sporadic cases of SSVD due to classical cardiovascular risk factors, such as hypertension, diabetes, smoking and dyslipidemia are much more common [2,7]. However, up to $2 / 3$ of sporadic SSVD patients have additional Alzheimer's disease pathology [8] and such mixed cases may be less suitable for studying pure VCI. On the other hand, hereditary forms of SSVD constitute a pure population of patients (or clear animal models) [9], suitable for the study of the relationship between SSVD and VCI [10,11]. Since hereditary forms of SSVD are rare, better knowledge of these disorders and recruitment of patients for studies may be achievable only through registries $[12,13]$. Such registries may prove helpful in understanding various genetic, clinical and epidemiological parameters of these disorders.

\section{Cadasil}

It has been shown that archetypal NOTCH3 mutations may be 100 -fold more frequent than previously thought, indicating that some mutations may result in mild phenotypes, sometimes clinically unrecognized [14]. Indeed, patients with a later onset of stroke [15], with a "benign" form of the disease presenting with stroke at the 8th decade [16], or with a normal-appearing 3T MRI at the 4th decade [17] are increasingly being recognized. Thus, it seems that the epidemiology of CADASIL is changing, characterized by an increasing prevalence and a relatively less severe presentation or a more favorable natural history and, patients from the Duch CADASIL registry and the neurovascular genetics clinic in Scotland were involved in such studies [14,15]. Better understanding and suspicion of the disease, resulting in recognition of relatively "benign" cases may be one cause of the above change. Additionally, it is now recognized that the classical cardiovascular risk factors may adversely affect CADASIL progression [18-23]. It is possible that control of these risk factors, which is currently strongly recommended $[11,24]$, contributed in a more favorable prognosis of the disease [25].

\section{COL4A1/A2-related disorders}

The phenotypic spectrum of COL4A1/A2-related disorders is continuously expanding [4]. Recently, epilepsy-predominant phenotypes have been recognized [26]. Late onset cases, asymptomatic cases, sporadic cases, de novo mutations and coexistence of multiple risk factors have also been described [4,27]. Furthermore, several variants of COL4A2 may be associated with sporadic SSVD resulting in deep intracerebral hemorrhage [28], while COL4A1/A2 variants may be associated with coronary heart disease in the young [29].

\section{HTRA1-related disease}

It is now recognized that some heterozygous HTRA1 mutations lead to an autosomal dominant form of SSVD $[30,31]$. This may present

*Correspondence to: George P Paraskevas, 1st Department of Neurology, School of Medicine, National and Kapodistrian University of Athens, Eginition Hospital, 72 Vas. Sofias Ave, Athens 11528, Greece, Tel: ++302107289286, Fax: ++307216474 , E-mail geoprskvs44@gmail.com

Key words: subcortical small vessel disease, vascular cognitive impairment, CADASIL, COL4, CARASIL

Received: January 28, 2019; Accepted: February 10, 2019; Published: February 14,2019 
with a relatively less severe phenotype in many (but not all) patients compared to the recessive form (CARASIL) [32] and seems to be more frequent than the later, accounting for up to $5 \%$ of hereditary SSVD $[30,32]$.

Thus, during the last 10-15 years cumulative data not only from registries [12,13], but also from specialized centers, databases and established consortia $[4,26,33,34]$ expanded our knowledge on these disorders. Furthermore, they provided evidence about the relative frequency of these disorders among inherited SSVD. It seems that the most frequent is CADASIL accounting for $58 \%$ of patients, followed by COL4A1/A2 mutations (at least 13\%) and heterozygous forms of HTRA 1 mutations $[4,30,32,33]$.

\section{Our local registry}

In the 1st department of Neurology of the National and Kapodistrian University of Athens, Greece, a local registry named "Migraine and Specific Vasculopathies Registry" was launched in 2011, for patients suffering of hereditary SSVD and hereditary forms of migraine. Clinical, genetic, neuropsychological, imaging and biochemical data are registered, including data on dementia biomarkers in cerebrospinal fluid (such as amyloid-beta, total tau and phospho-tau proteins). Since 2011, we have identified and published 3 novel families with CADASIL, 2 of which had atypical features $[35,36]$ and one had oligosymptomatic presentation [37]. Thus, we identified one new CADASIL family every 2.5 years. We have also described a new oligosymptomatic patient [38] from a 4th CADASIL family previously described in our department [39]. The above families consist of at least 12 alive CADASIL patients. A family with a phenocopy of COL4-related disease (but no COL4A1/ A2 mutation) was also described [40]. Additionally we have been involved in the description of the 1st patient with heterozygous HTRA1 mutation in Greece [41].

\section{Conclusion}

Although local, since our department is a tertiary referral center, the registry may cover a population much wider than the one expected from geographical boundaries and the same holds trough for all local registries in academic centers. However, nation-wide registries supported by many collaborating specialized centers are preferable, while international registries may be required.

\section{Authorship}

George P. Paraskevas: conception and design, acquisition and interpretation of literature data, drafting, final approval, guarantor.

Vasilios C. Constantinides: conception and design, analysis and interpretation of literature data, critical revision, final approval, guarantor.

Evangelia Kararizou: conception and design, critical revision, final approval, guarantor.

Sophia Vassilopoulou: conception and design, analysis and interpretation of literature data, critical revision, final approval, guarantor.

Panagiotis G. Paraskevas: acquisition and analysis of literature data, drafting, final approval, guarantor.

Elisabeth Kapaki: conception and design, critical revision, final approval, guarantor

\section{References}

1. Choi JC (2015) Genetics of cerebral small vessel disease. J Stroke 17: 7-16. [Crossref]

2. Wallin A, Román GC, Esiri M, Kettunen P, Svensson J, et al. (2018) Update on Vascular Cognitive Impairment Associated with Subcortical Small-Vessel Disease. J Alzheimers Dis 62: 1417-1441. [Crossref]

3. Chabriat H1, Joutel A, Dichgans M, Tournier-Lasserve E, Bousser MG (2009) Cadasil. Lancet Neurol 8: 643-653. [Crossref]

4. Meuwissen ME, Halley DJ, Smit LS, Lequin MH, Cobben JM, et al. (2015) The expanding phenotype of COL4A1 and COL4A2 mutations: clinical data on 13 newly identified families and a review of the literature. Genet Med 17: 843-853. [Crossref]

5. Tikka S, Baumann M, Siitonen M, Pasanen P, Pöyhönen M, et al. (2014) CADASIL and CARASIL. Brain Pathol 24: 525-544. [Crossref]

6. Søndergaard CB, Nielsen JE, Hansen CK, Christensen H (2017) Hereditary cerebral small vessel disease and stroke. Clin Neurol Neurosurg 155: 45-57. [Crossref]

7. Wallin A, Kapaki E, Boban M, Engelborghs S, Hermann DM, et al. (2017) Biochemical markers in vascular cognitive impairment associated with subcortical small vessel disease - A consensus report. BMC Neurol 17: 102.[Crossref]

8. Attems J, Jellinger KA (2014) The overlap between vascular disease and Alzheimer's disease-lessons from pathology. BMC Med 12: 206. [Crossref]

9. Joutel A, Faraci FM (2014) Cerebral small vessel disease: insights and opportunities from mouse models of collagen IV-related small vessel disease and cerebral autosoma dominant arteriopathy with subcortical infarcts and leukoencephalopathy. Stroke 45: 1215-1221. [Crossref]

10. Craggs LJ, Yamamoto Y, Ihara M, Fenwick R, Burke M, et al. (2014) White matter pathology and disconnection in the frontal lobe in cerebral autosomal dominant arteriopathy with subcortical infarcts and leukoencephalopathy (CADASIL) Neuropathol Appl Neurobiol 40: 591-602. [Crossref]

11. Paraskevas GP, Constantinides VC, Paraskevas PG, Kapaki E (2018) Inherited Cerebral Small Vessel Disease, Vascular Cognitive Impairment, Classical Cardiovascular Risk Factors, and Preventive Measures - Lessons from Cerebral Autosomal Dominant Arteriopathy with Subcortical Infarcts and Leukoencephalopathy. Asclepius Med Res Rev 1: 1-6.

12. Inzitari D, Quattrone A, Federico A (2006) Cerebral Autosomal Dominant Arteriopathy with Subcortical Infarcts and Leukoencephalopathy (CADASIL): a proteiform neurological disease of expanding importance. Reasons for establishing an Italian Registry. Neurol Sci 27: 301-302. [Crossref]

13. Bersano A, Baron P, Lanfranconi S, Trobia N, Sterzi R, et al. (2012) Lombardia GENS a collaborative registry for monogenic diseases associated with stroke. Funct Neurol 2012 27: 107-117. [Crossref]

14. Rutten JW, Dauwerse HG, Gravesteijn G, van Belzen MJ, van der Grond J, et al. (2016) Archetypal NOTCH3 mutations frequent in public exome: implications for CADASIL. Ann Clin Transl Neurol 3: 844-853. [Crossref]

15. Moreton FC, Razvi SS, Davidson R, Muir K W (2014) Changing clinical patterns and increasing prevalence in CADASIL. Acta Neurol Scand 130: 197-203. [Crossref]

16. Pescini F, Bianchi S, Salvadori E, Poggesi A, Dotti MT, et al. (2008) A pathogenic mutation on exon 21 of the NOTCH3 gene causing CADASIL in an octogenarian paucisymptomatic patient. J Neurol Sci 267: 170-173. [Crossref]

17. Samões R, Alves JE, Taipa R, Silva J, Melo Pires M, et al. (2016) CADASIL: MRI may be normal in the fourth decade of life - a case report. Cephalalgia 36: 1082-1085. [Crossref]

18. Adib-Samii P, Brice G, Martin RJ, Markus HS (2010) Clinical spectrum of CADASIL and the effect of cardiovascular risk factors on phenotype. Study in 200 consecutively recruited individuals. Stroke 41: 630-634. [Crossref]

19. Ling Y, De Guio F, Duering M, Jouvent E, Hervé D, et al. (2017) Predictors and Clinical Impact of Incident Lacunes in Cerebral Autosomal Dominant Arteriopathy With Subcortical Infarcts and Leukoencephalopathy. Stroke 48: 283-289. [Crossref]

20. Lee JS, Kang CH, Park SQ, Choi HA, Sim KB (2015) Clinical significance of cerebral microbleeds locations in CADASIL with R544C NOTCH3 mutation. PLoS One 10: e0118163. [Crossref]

21. Ciolli L, Pescini F, Salvadori E, Del Bene A, Pracucci G, et al. (2014) Influence of vascular risk factors and neuropsychological profile on functional performances in CADASIL: results from the MIcrovascular LEukoencephalopathy Study (MILES). Eur J Neurol 21: 65-71. [Crossref] 
22. Chabriat H, Hervé D, Duering M, Godin O, Jouvent E, et al. (2016) Predictors of Clinical Worsening in Cerebral Autosomal Dominant Arteriopathy With Subcortical Infarcts and Leukoencephalopathy: Prospective Cohort Study. Stroke 47: 4-11. [Crossref]

23. Viswanathan A, Guichard JP, Gschwendtner A, Buffon F, Cumurcuic R, et al. (2006) Blood pressure and haemoglobin Alc are associated with microhaemorrhage in CADASIL: a two-centre cohort study. Brain 129: 2375-2383. [Crossref]

24. Di Donato I, Bianchi S, De Stefano N, Dichgans M, Dotti MT, et al. (2017) Cerebral Autosomal Dominant Arteriopathy with Subcortical Infarcts and Leukoencephalopathy (CADASIL) as a model of small vessel disease: update on clinical, diagnostic, and management aspects. BMC Med 15:41. [Crossref]

25. Mykkänen K, Junna M, Amberla K, Bronge L, Kääriäinen H, et al. (2009) Different clinical phenotypes in monozygotic CADASIL twins with a novel NOTCH3 mutation. Stroke 40: 2215-2218. [Crossref]

26. Zagaglia S, Selch C, Nisevic JR, Mei D, Michalak Z, et al. (2018) Neurologic phenotypes associated with COL4A1/2 mutations: Expanding the spectrum of disease. Neurology 91: e2078-e2088. [Crossref]

27. Magnin E, Ayrignac X, Berger E, Mine M, Tournier-Lasserve E, et al. (2014) Late diagnosis of COL4A1 mutation and problematic vascular risk factor management. Eur Neurol 72: 150-152. [Crossref]

28. Rannikmäe K, Davies G, Thomson PA, Bevan S, Devan WJ, et al. (2015) Common variation in COL4A1/COL4A2 is associated with sporadic cerebral small vessel disease. Neurology 84: 918-926. [Crossref]

29. Hixson JE, Jun G, Shimmin LC, Wang Y, Yu G, et al. (2017) Whole Exome Sequencing to Identify Genetic Variants Associated with Raised Atherosclerotic Lesions in Young Persons. Sci Rep 7: 4091. [Crossref]

30. Verdura E, Hervé D, Scharrer E, Amador Mdel M, Guyant-Maréchal L, et al. (2015) Heterozygous HTRA1 mutations are associated with autosomal dominant cerebral small vessel disease. Brain 138: 2347-2358. [Crossref]

31. Nozaki H, Kato T, Nihonmatsu M, Saito Y, Mizuta I, et al. (2016) Distinct molecular mechanisms of HTRA1 mutants in manifesting heterozygotes with CARASIL. Neurology 86: 1964-1974. [Crossref]
32. Di Donato I, Bianchi S, Gallus GN, Cerase A, Taglia I, et al. (2017) Heterozygous mutations of HTRA1 gene in patients with familial cerebral small vessel disease. CNS Neurosci Ther 23: 759-765. [Crossref]

33. Ayrignac X, Carra-Dalliere C, Menjot de Champfleur N, Denier C, Aubourg P, et al (2015) Adult-onset genetic leukoencephalopathies: a MRI pattern-based approach in a comprehensive study of 154 patients. Brain 138(Pt 2): 284-292. [Crossref]

34. Bianchi S, Zicari E, Carluccio A, Di Donato I, Pescini F, et al. (2015) CADASIL in central Italy: a retrospective clinical and genetic study in 229 patients. J Neurol 262: 134-141. [Crossref]

35. Paraskevas GP, Bougea A, Synetou M, Vassilopoulou S, Anagnostou E, et al. (2014) CADASIL and autoimmunity: coexistence in a family with the R169C mutation at exon 4 of the NOTCH3 gene. Cerebrovasc Dis 38: 302-307. [Crossref]

36. Paraskevas GP, Constantinides VC, Bougea A, Gerakoulis E, Yapijakis C, et al (2016) Cerebral autosomal dominant arteriopathy with subcortical infarcts and leukoencephalopathy presenting with postpartum psychosis and late-onset stroke. Future Neurol 1: 207-213.

37. Paraskevas GP, Constantinides VC, Yapijakis C, Kararizou E, Kapaki EN, Bouge A (2018) Recognition of cerebral autosomal dominant arteriopathy with subcortical infarcts and leukoencephalopathy (CADASIL) in two oligosymptomatic sisters with low CADASIL scale scores and a venous dysplasia: Report of a novel Greek family. J Stroke Cerebrovasc Dis 27: e191-e195. [Crossref]

38. Paraskevas GP, Vassilopoulou S, Anagnostou E, Constantinides VC, Andreadou E, et al. (2018) Tension headaches and vertigo in a cerebral autosomal dominant arteriopathy with subcortical infarcts and leukoencephalopathy patient. Asclepius Med Res Rev 1: 1-3.

39. Andreadou E, Papadimas G, Sfagos C (2008) A novel heterozygous mutation in the NOTCH3 gene causing CADASIL. Swiss Med Wkly 138: 614-617. [Crossref]

40. Bougea A, Kapaki E, Constantinides V, Yapijakis C, Paraskevas GP (2018) An unusual phenocopy of the HANAC syndrome without genetic involvement of COL4A1/ COL4A2. Acta Neurol Belg 118: 135-136. [Crossref]

41. Bougea A, Velonakis G, Spantideas N, Anagnostou E, Paraskevas G, et al. (2017) The first Greek case of heterozygous cerebral autosomal recessive arteriopathy with subcortical infarcts and leukoencephalopathy: An atypical clinico-radiological presentation. Neuroradiol J 30: 583-585. [Crossref]

Copyright: (C2019 Paraskevas GP. This is an open-access article distributed under the terms of the Creative Commons Attribution License, which permits unrestricted use, distribution, and reproduction in any medium, provided the original author and source are credited. 